\title{
11 Chickpea participatory variety selection for the vertisol of the watershed
}

\author{
Tewodros Tesfaye, Getachew Tilahun \\ and Kibrsew Mulat
}

\section{Introduction}

Chickpea is one of the most important food grains in the diets of Ethiopian people. Ethiopia is the largest producer of chickpea in Africa, and the sixth largest producer in the world, with over 200,000 hectares under cultivation and annual production of 4 million quintals (CSA, 2011). The crop is propoor in that it has high potential for improving the livelihoods of the rural poor in Ethiopia. It is an important source of protein in the people's diet, an important rotation crop to improve soil fertility and it is also an important cash source. Similarly, chickpea is the main leguminous crop widely produced in the watershed. However, farmers grow traditional, low-yielding and disease- and pest-susceptible varieties, despite the fact that several high yielding, diseaseresistant, pest-resistant and drought-tolerant varieties have been developed by the National Agricultural Research System (NARS) and the International Center for Agricultural Research in the Dry Areas (ICARDA). The local varieties are low yielding and susceptible to wilt; so introducing high-yielding and adaptable improved chickpea varieties would increase farmers' productivity and thus their livelihoods. Therefore, an experiment on participatory selection of chickpea varieties was conducted with the objectives of selecting adaptive and high-yielding improved chickpea varieties through farmers' participation and evaluating the effect of rhizobium inoculation on the productivity of chickpea.

\section{Materials and methods}

\section{Description of the study area}

The study was conducted on the vertisol of the Gumara-Maksegnit watershed. The watershed is located between $12^{\circ} 23^{\prime} 53^{\prime \prime}$ to $12^{\circ} 30^{\prime} 49^{\prime \prime}$ latitude and $37^{\circ} 33^{\prime} 39^{\prime \prime}$ to $37^{\circ} 37^{\prime} 14^{\prime \prime}$ longitude and at an altitude of 1,953 metres above sea level in North Gondar administrative zone. The long term average annual rainfall is about $1,052 \mathrm{~mm}$. The mean minimum and maximum temperatures of the area are $13.3^{\circ} \mathrm{C}$ and $28.5^{\circ} \mathrm{C}$. 


\section{Experimental design and procedures}

A participatory variety selection trial was conducted in the 2011 and 2012 cropping seasons. Five improved chickpea varieties (Arerti, Shasho, Monino, Habru and DZ-10-4) and one local variety were evaluated with and without rhizobium inoculation for their adaptation and yield. The experimental design was randomized complete block design (RCBD) in a factorial arrangement. The experiment was conducted on-farm using each farmer's field as a replication. Planting was made at spacings of $30 \mathrm{~cm}$ between rows and $10 \mathrm{~cm}$ between plants during mid to late August. Plot sizes were $5 \mathrm{~m} \times 10 \mathrm{~m}$. The whole plot was harvested. Seeds of each variety were inoculated with rhizobium at the rate of $120 \mathrm{gm}$ rhizobium/ha. Neither nitrogen nor phosphorus fertilizers were applied. Weeding and other agronomic practices were carried out as per the recommendation. Data on heading and maturity dates, plant height, stand count, disease incidence, 100 seed weight and grain yield was collected. Plant height was measured from five randomly selected plants. Disease data was transformed before analysis. Combined analyses of variance were performed using data across locations and years. At pod setting the varieties were evaluated by farmers' research and extension group (FREG) members, the district office of agriculture experts, development agents and researchers at Gondar Agricultural Research Center. Prior to evaluation farmers set their own criteria and evaluated each variety against the set criteria and finally ranked the varieties.

\section{Results and discussions}

The results of the analysis of variance showed that varieties differ significantly in all the parameters considered, except for plant height (Table 11.2). However, the main effect of rhizobium inoculation and the interaction effect of rhizobium inoculation with varieties did not show any significant differences (Table 11.1). This may be due to the fact that the indigenous rhizobium could have been functioning well. However, this deserves further study.

Varieties vary significantly in days to flowering and maturity and Habru flowered and matured significantly earlier than the other varieties (Table 11.2). The highest significant grain yield was recorded for Arerti and the local variety, but the early-maturing variety Habru gave the lowest yield (Table 11.2). Unlike Arerti, the highest yield of the local variety could be associated with it having the highest number of pods per plant and seeds per pod (Table 11.2). Monino followed by Habru had significantly bigger seed sizes (Table 11.2). The largest seed size was recorded for Monino (57.4 g) and the lowest was recorded for DZ-10-4 (11.8 g). The market demand for large seeded varieties is high both in national and international markets. With regard to diseases, Monino was most affected as it was planted without any dressing with pesticides. Arerti and Shasho are relatively tolerant (Table 11.2). 


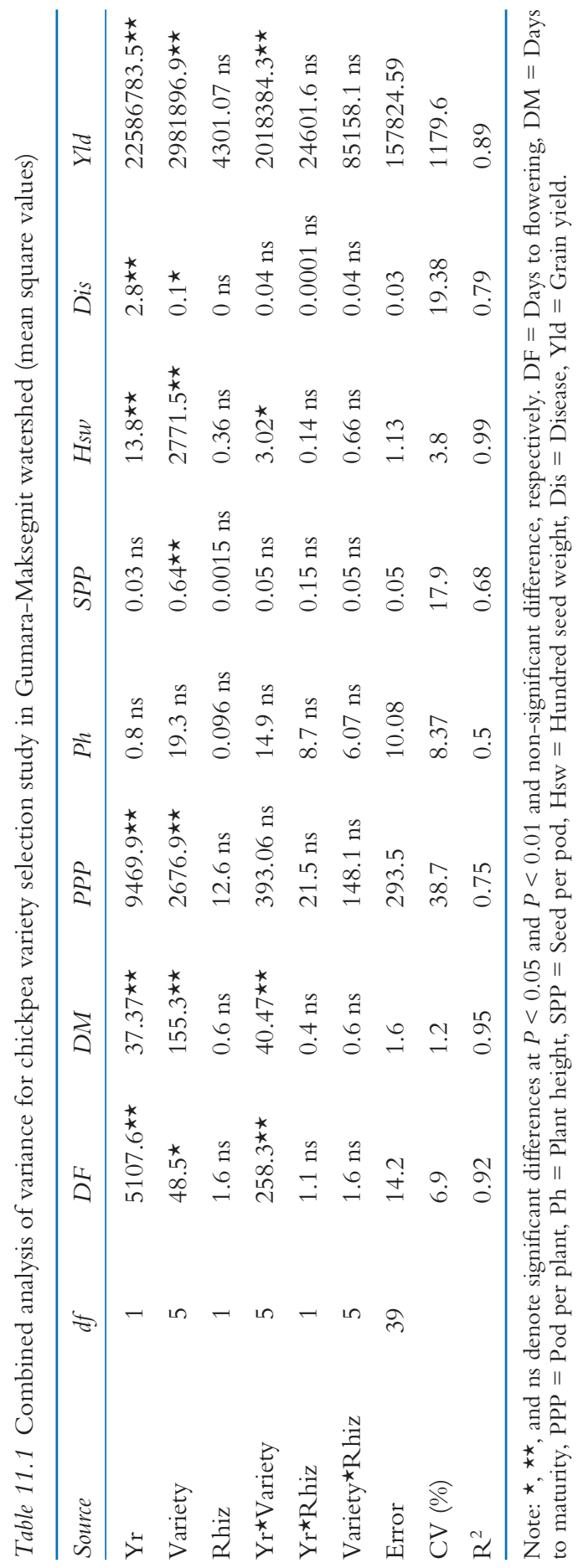




\section{Results of farmers' evaluation}

Farmers evaluated the varieties using their own criteria and selected Arerti and Shasho as their first and second choice respectively (Table 11.3). Farmers' evaluation and selection matches the researchers' evaluation and selection (Table 11.2).

Table 11.2 Yield and yield components of chickpea varieties in Gumara-Maksegnit watershed

\begin{tabular}{llllllll}
\hline Varieties & DF & DM & $\begin{array}{l}\text { Yld } \\
(\mathrm{kg} / \mathrm{ha})\end{array}$ & PPP & SPP & $\begin{array}{l}\text { Hsw } \\
(\mathrm{g})\end{array}$ & $\begin{array}{l}\text { Dis } \\
(\%)\end{array}$ \\
\hline Arerti & $57^{\mathrm{a}}$ & $112^{\mathrm{a}}$ & $1705^{\mathrm{a}}$ & $45.5^{\mathrm{b}}$ & $1.1^{\mathrm{c}}$ & $25.9^{\mathrm{d}}$ & $0.78^{\mathrm{c}}$ \\
Shasho & $56^{\mathrm{a}}$ & $106^{\mathrm{c}}$ & $1293^{\mathrm{b}}$ & $45.8^{\mathrm{b}}$ & $1.1^{\mathrm{c}}$ & $27.7^{\mathrm{c}}$ & $0.78^{\mathrm{c}}$ \\
Monino & $55^{\mathrm{a}}$ & $104^{\mathrm{d}}$ & $282^{\mathrm{d}}$ & $16.18^{\mathrm{c}}$ & $1.1^{\mathrm{c}}$ & $57.4^{\mathrm{a}}$ & $1.05^{\mathrm{a}}$ \\
Habru & $50^{\mathrm{b}}$ & $100^{\mathrm{e}}$ & $924^{\mathrm{c}}$ & $39.38^{\mathrm{b}}$ & $1.2^{\mathrm{bc}}$ & $30.7^{\mathrm{b}}$ & $0.94^{\mathrm{b}}$ \\
DZ-10-4 & $54^{\mathrm{a}}$ & $107^{\mathrm{b}}$ & $1123^{\mathrm{bc}}$ & $53.5^{\mathrm{ab}}$ & $1.7^{\mathrm{a}}$ & $11.8^{\mathrm{e}}$ & $0.96^{\mathrm{ab}}$ \\
Local & $54^{\mathrm{a}}$ & $103^{\mathrm{d}}$ & $1752^{\mathrm{a}}$ & $65.15^{\mathrm{a}}$ & $1.4^{\mathrm{b}}$ & $12.4^{\mathrm{e}}$ & $0.88^{\mathrm{bc}}$ \\
Mean & 54.4 & 105 & 33.7 & 44.3 & 1.3 & 3.8 & 0.9 \\
CV (\%) & 6.9 & 1.2 & 1179.6 & 38.7 & 17.9 & 27.67 & 19.38 \\
\hline
\end{tabular}

Note: Means in a column followed by different letter(s) are significantly different at $P \leqslant 0.05$, $\mathrm{DF}=$ Days to flowering, $\mathrm{DM}=$ Days to maturity, $\mathrm{PPP}=$ Pod per plant, $\mathrm{SPP}=$ Seed per pod, Hsw $=$ Hundred seed weight, Dis $=$ Disease, Yld $=$ Grain yield.

Table 11.3 Farmers' evaluation on the chickpea varieties using their own criteria

\begin{tabular}{|c|c|c|}
\hline Variety & Farmers' evaluation & Rank \\
\hline Arerti & $\begin{array}{l}\text { Has large number of pods/plant, has } \\
\text { two seeds/pod, is resistant to drought, has } \\
\text { vigorous growth and good population, } \\
\text { has good branching, has large seed size. }\end{array}$ & First \\
\hline Shasho & $\begin{array}{l}\text { Has large number of pods/plant, is } \\
\text { tolerant to drought, has good branching, } \\
\text { has large seed size. }\end{array}$ & Second \\
\hline Monino & Has very poor stand. & Not selected \\
\hline Habru & $\begin{array}{l}\text { Has large seed size, is early maturing, } \\
\text { has poor branching, is tolerant to } \\
\text { drought. }\end{array}$ & Fourth \\
\hline DZ-10-4 & & Not selected \\
\hline Local & $\begin{array}{l}\text { Has large number of pods/plant, has } \\
\text { two seeds/pod, has good branching, } \\
\text { has small seed size. }\end{array}$ & Third \\
\hline
\end{tabular}


182 T. Tesfaye et al.

\section{Conclusions}

Chickpea is an important crop in the watershed. It is a source of nutritious diet, income and is an important rotation crop for restoring soil fertility. However, farmers are growing wilt susceptible, small seeded and less market demanded chickpea varieties. Therefore, based on the results of the adaptation study farmers in the watershed are advised to grow Arerti and Shasho varieties.

\section{References}

Central Statistical Agency (CSA) 2011. 'Report on area and production of major crops (private peasant holdings, Meher season)'. CSA, statistical bulletin, Vol 1, Addis Abiba, Ethiopia. 